\title{
Los animales en los haikus de José JuAn Tablada: TAXONOMÍA DE UNA FAUNA INTERIOR
}

\author{
David Vásquez Hurtado* \\ Fort Lewis College
}

\begin{abstract}
Resumen: En el libro de haikus titulado Jarro de flores, del poeta mexicano José Juan Tablada (1871-1945), los animales son instancias de percepción hacia la reconstrucción de la voz poética en un peregrinaje interior. Comienza con la búsqueda de una voz primitiva representada en el sapo y el perro. El próximo destino será el jardín japonés con animales diminutos evanescentes a la percepción. El siguiente será un paisaje hispanoamericano de animales grandes ya sometidos a la mirada. Posteriormente el poeta asume el control de su voz poética en un paisaje oceánico, con animales marítimos elaborados mediante la intertextualidad. El punto de llegada es una integración de estas diversas instancias de percepción.
\end{abstract}

Palabras clave: José Juan Tablada; animales; haikú; Modernismo; orientalismo.

Recibido: 9 de octubre de 2016

Aprobado: 16 de octubre de 2016

\section{ANimals in the Haikus of José Juan Tablada: Taxonomy OF AN INNER FAUNA}

\begin{abstract}
In his book of haikus entitled A Vase of Flowers, by the Mexican poet José Juan Tablada (1871-1945), animals comprise perceptual stages toward the reconstruction of the poetic voice in an inner pilmigrage. It starts with the search of a primitive voice embodied in the toad and the dog. The next stage is a Japanese garden with minuscule animals who escape to perception. The next stage will be a Hispanoamerican landscape with large anaimals subdued to the poetic gaze. Subsequently the poet takes control on his poetic voice in an

*David Vásquez Hurtado. Ph.D. en Estudios Hispánicos (2016) de la Universidad de Florida (EE. UU.). Actualmente es Profesor de tiempo completo en Fort Lewis College en Durango, Colorado (EE. UU.), donde enseña diversos cursos de español, cultura y literatura. Se interesa por los estudios culturales y la historia intelectual, así como también la monstruosidad y los imaginarios de magia y ocultismo en el mundo hispánico. Dirección electrónica: dvasquezhurtado@fortlewis.
\end{abstract} $\underline{\text { edu }}$ 
oceanic landscape, with sea animals elaborated through intertextuality. Final destination is the integration of those perceptual stages into his poetic voice.

Key words: José Juan Tablada; haiku; animals; modernism; orientalism.

El poeta mexicano José Juan Tablada (1871-1945) publica en 1922 un libro de haikus ${ }^{1}$ titulado Jarro de flores: Disociaciones líricas. En esta serie poética, pájaros, sapos e insectos y toda suerte de minúsculas formas vivientes, íntimamente próximas, aparecen registradas o imaginadas en un gesto que puede entenderse como una comunión con lo natural, con esa vida desnuda que Gabriel Giorgi (2008) entiende como un espacio indistinguible entre lo humano y lo meramente biológico. En el viaje extático de Tablada a través de ese espacio natural, parecen confluir tanto una experiencia estética modernista introspectiva como lo oriental y lo exótico. Esto no solo se refleja en las formas mínima de sus poemas, sino también en lo relativo a lo espiritual. El haiku está íntimamente ligado a su naturaleza sagrada, a la búsqueda del satori o la iluminación (García, 1998, p. 98). El peregrinaje por la naturaleza, que es también motivo propio de la poesía japonesa, se convierte en mecanismo de búsqueda de una experiencia espiritual y a la vez estética (Tinajero, 2004, p. 108-109).

Cuando el haiku es descubierto por los poetas modernistas, se produce un mestizaje entre los motivos tradicionales japoneses y las preocupaciones estéticas del poeta latinoamericano. En el libro Jarro de Flores, ese peregrinaje espiritual demuestra un afán por integrar los elementos orientalistas con la memoria cultural autóctona. Los animales constituyen instancias de percepción que revelan dimensiones variadas de ese viaje interior. El libro propone una simbiosis entre el sonido de los animales y la voz poética. Esto lo lleva a la percepción efímera y fugaz de los animales pequeños, para pasar por la presencia estable de los animales más grandes que han sido sometidos por la mirada humana. Llega entonces a un estadio donde la voz poética logra integrar

\footnotetext{
${ }^{1}$ El haiku es un modelo de poesía corta, tradicional de Japón, conformado por solo tres versos de cinco, siete y cinco sílabas. En este modelo se busca la expresión instantánea de una imagen de la naturaleza. En la poesía hispanoamericana se ha adaptado la forma corta del poema de tres versos, pero con silabificación variable.
} 
todas esas instancias de percepción donde lo efímero, representado en animales pequeños, coexiste con lo permanente, representado en los grandes. De esta manera, el poeta reconstruye una mirada a la vez efímera y estable. La tradición japonesa le permite explorar la fugacidad perceptual, mientras que la estética modernista le permite volver sobre la percepción perenne.

El "japonismo" de Tablada ha despertado continuamente interés en la crítica. Atsuko Tanabe (1981) dedicó un libro entero a explorar la poética de este autor y su relación con la estética japonesa en todos los aspectos, particularmente en cuanto a la manifiesta influencia de la pintura en su poesía. También se ha documentado ampliamente cómo Tablada siguió de cerca la tradición de las formas poéticas del Japón, su estética breve, apropiándose de ella y logrando amoldar "los haikus japoneses a su forma mexicana de ver y sentir la vida, rescatando la imagen de los vuelos retóricos y ornamentales del modernismo" (NagyZegmy, 2008, p. 217). De igual forma, ha sido descrito cómo Tablada no solo asumió la estructura de esa poesía lejana y exótica, sino "los conceptos sintoístas y zenistas, los cuales exigen una íntima relación entre el ser, la naturaleza y el universo" (Tinajero, 2004, p. 115), en los que existe una apropiación de elementos culturales de Oriente. El mundo natural representado en las pinturas japonesas que inspiraron a Tablada "era digna de ser admirada, contemplada y descrita a través de un ojo que daba un paso más allá, que trataba de darle un sentido búdico a la aparente simplicidad de un cuadro" (Tinajero, 2004, p. 118). El poeta mexicano se habría percatado de dos grandes variantes en el arte en relación con la naturaleza:

...la del artista que, consciente de la distancia entre hombre y naturaleza, o, en términos más contemporáneos, consciente del no encuentro de una naturaleza para el hombre, intenta un abrazo mimético con lo natural, y la perspectiva que se reviste como adversaria, la del artista que, igualmente sabedor de la escisión entre hombre y naturaleza, busca ahondarla y erigir como territorio natural su propia creación (Hernández Palacios, 2001, p. 110). 


\section{DAVID VÁSQUEZ HURTADO}

Los haikus recopilados en Jarro de Flores permiten apreciar dinámicas de simbiosis, pero también de separación entre lo humano y lo natural. Tablada retrata episodios que ocurren en una naturaleza que es a la vez indefinida, efímera y cercana, así como otros que reflejan un distanciamiento literario que la complejiza. Sin embargo, lo que se refiere a los animales no ha sido estudiado en su particularidad, y constituye una aproximación crítica que podría revelar aspectos muy significativos de su poesía y esa relación contradictoria con lo natural.

La poesía modernista hispanoamericana encuentra en la francesa su referente inmediato y mantiene un diálogo permanente con ella. Los poetas franceses de la segunda mitad del siglo XIX se convierten en modelo estético de transición entre las innovaciones de los años ochenta hasta la aparición de las vanguardias (Del Olmo y Díaz, 2008, p. 10). La construcción estética del modernismo connota un proceso de subjetivación sistemática que consiste en sustituir la primacía del mundo exterior por el interior. Para los poetas de este movimiento, "la inspiración poética, como la pictórica, era una especie de 'visión' por la que el artista se abstraía en su mundo imaginario" (González Duro, 1994-1996, p. 191). Esto encarnaba un descontento paradójico de los poetas modernistas frente a un mundo "moderno" del que había que escapar. Uno de los mecanismos poéticos era poner la mirada en otras latitudes, en particular a Oriente, el cual era mirado desde Occidente con una visión romantizada. En el caso de Tablada, esto implica la adopción de las formas poéticas y espirituales japonesas.

La apropiación que hace Tablada de la poesía japonesa aparece así como un gesto, si se quiere, profundamente modernista. El uso de formas poéticas exóticas, de lugares lejanos y de animales diminutos, sería comparable con emprender un viaje, lo que implica a su vez una condición contemplativa e interior de esa poesía, una forma de introspección. La poética breve, con poemas de tres versos como el haiku, permite expresar la fragilidad de la percepción, concepto propio del budismo zen. La poesía se concibe como "una forma de vislumbrar el significado de las cosas, una forma de llegar a la iluminación (satori), de descubrir el sentido del ilógico mundo fenoménico y de la falsedad de nuestro yo" (De la Fuente, 2009, pp. 64-65). Sin embargo, esa captación 
irracional del instante también tiene como vehículo la impresión pictórica: "precisamente, remite a las tesis mallarmeanas sobre el lenguaje esencial, la palabra que hace desaparecer la materialidad de las cosas y que podemos conectar con el 'momento haiku', la intuición (o iluminación) que apresa mágicamente esa esencialidad" (De la Fuente, 2009 , p. 70). La poesía sobrepasa la necesidad de representar la realidad para concebirse como vehículo de fusión entre el poeta y la existencia. En la estética de Tablada la captación de la impresión (impresionismo) como imagen de un instante.

En esta clave poética espiritual, hay una capacidad especial de hacerse parte de variadas manifestaciones de la naturaleza como plantas, rocas, montañas y animales, y responder a su esencia mutable y transitoria. Tablada escribe sobre libélulas, hormigas, luciérnagas y aves de todo tipo, tal como lo hicieron Matsuo Basho (1644 - 1694) o Kobayashi Issa (1763-1828). Parece compartir con ellos un profundo amor por todos los seres vivientes, que en sus haikus se convierte en imagen plástica viva; pero este énfasis también "nos recuerda aquella 'plasticidad de la poesía', tan añorada con calurosa emoción por los poetas modernistas" (Nagy-Zegmy, 2008, p. 113). En el caso de Tablada, la apreciación de la voz de los animales y la contemplación de su forma moldean la estética de un camino espiritual en su recorrido interior.

Este artículo analiza las cinco partes del poema donde los animales se constituyen como instancias de percepción en ese viaje interior: "De camino", "En el jardín", "Bestiario", "Marinas" y "Dramas mínimos"2. Cada serie de poemas constituye un alto en el camino que posibilita la interacción con diversos animales que constituyen instancias de percepción. Ellos dirigen al poeta hacia una consciencia alterada y dispersa que busca reorganizarse en un camino a lo esencial. Los elementos reorganizadores están signados por una estructura estética complementaria entre lo orientalista y modernista, que matiza las percepciones de sí en su relación con los animales. "De camino" enfatiza en la percepción sonora e inocente de los animales de la niñez y la granja; "En el jardín” pone el énfasis sobre la percepción

\footnotetext{
${ }^{2}$ Se utiliza la edición de 1922 para determinar la separación en estas cinco partes que hace originalmente Tablada, pero para el paginado se usa una versión más accesible al lector que es la bilingüe de Scott Britton (2016).
} 
efímera y huidiza del vuelo del animal minúsculo; "Bestiario" amplía el espectro visual al poner el foco sobre animales grandes, sometidos por la violencia humana a esa percepción como en un zoológico; en "Marinas", la percepción aparece completamente encerrada en cánones poéticos, referencias literarias y pictóricas; "Dramas mínimos" constituye un retorno abrupto al jardín de los animales pequeños.

\section{De camino, el paisaje interior}

En Tablada existe una relación muy fuerte entre poesía e imagen pictórica. Era un gran admirador y coleccionista de las estampas de Hiroshige, cuyo nombre real era Ando Tokutaro (1797-1858). Estas lo inspiraron a percibir los estrechos lazos que hay entre esta pintura, el estilo monocromático sumi-e y el haiku, y que es "producto de siglos de cultura y disciplina, cuya expresión, fuente de espiritualidad para el arte zen, es el clima de una meditación larga y concentrada" (NagyZegmy, 2008, p. 226). La primera serie de poemas de Jarro de Flores, titulada "De camino", parece un relato de viaje de estilo modernista a los paisajes de Hiroshige, pero ese camino hacia Japón sería en realidad un viaje hacia el interior, a través de una confluencia entre la impresión sonora y visual, para evocar imágenes de su infancia en un pasado rural.

El primer animal que aparece en el libro es el sapo, que marca el derrotero semántico de su serie poética. El sapo se erige como metáfora de la voz poética que guía el camino al pasado, en el poema "Hongo": "Parece la sombrilla / de un hongo policromo / de un sapo japonista" (2016/1922, p. 64). El hongo puede asociarse a ese mecanismo alucinógeno que conduce a los paraísos artificiales de la estética modernista. Resguarda al sapo de los elementos naturales como el agua; por eso, es "sombrilla". En la poesía japonesa, el sapo está relacionado a la llegada de la lluvia, como en el haiku de Fukuda Chiyo-ni (17031775): "nubes de lluvia / el sapo / extiende su barriga!" (Cobb, 2002, p. 18$)^{3}$ y suele ser un tema recurrente tanto de las pinturas de Tokutaro como de la plástica oriental.

${ }^{3}$ Las traducciones del inglés al español son nuestras. Se citan en paréntesis los editores respectivos de las colecciones del haiku citado. 
Del sapo se emplea el adjetivo "japonista", que denota una cualidad que se refiere a la búsqueda intelectual de Tablada, su inclinación por el conocimiento de la tradición japonesa. Existe una homofonía entre la palabra japonesa para sapo, kaeru, y el verbo japonés que significa "regresar" (también kaeru), que indica un movimiento hacia el lugar de donde se parte o donde se ha nacido. El sapo, pues, en la lengua japonesa es también regreso. El sapo japonista es la voz poética que regresa por los caminos de la infancia.

En "De camino" también aparecen los animales domésticos como vehículos de la memoria y de impresiones sonoras que conectan imágenes entrañables. Uno de ellos es el perro del haiku "De camino": "Seis horas a pie por la montaña, / ladra un perro lejano... / ¿Habrá qué comer en la cabaña...?" (2016/1922, p. 66). En el verso intermedio, el perro se introduce entre la montaña y la cabaña como un mediador del recuerdo. Es un sonido que conecta las imágenes visuales de un lugar de la naturaleza (la montaña) con el espacio de habitabilidad humana (la cabaña). Aquí el ladrido del perro está congelado en la memoria como un sonido que pertenece al mundo de lo no-humano y que Tablada asocia con una imagen congelada en sus recuerdos. Tablada se había sentido atraído por su entorno natural y, por tanto, la estética del Japón le permitió aplicar en su obra una sensibilidad hacia esos espacios (Hernández Palacios, 2011).

Otro de esos animales es el gallo, del haiku "Tormenta": "Tormenta en el camino... / cuando el gallo cantaba / anunciando ya el próximo cortijo!" (2016/1922, p. 66). El canto del gallo sirve como mediador entre dos espacios de lo humano: el camino y el cortijo. El perro y el gallo, como entidades sonoras que interrumpen el silencio, se convierten en el signo que marca una parada transitoria en el viaje. El ladrido y el canto del gallo están situados en un lugar de la memoria que le permite a la voz poética encontrarse a sí misma en el recuerdo. Estos animales son motivos propios de su entorno cultural latinoamericano que vienen a enriquecer la escena japonista y a producir conexiones entre la casa de la que se parte y el mundo natural. Esto lo conduce a un espacio mucho más japonista como el jardín, donde se encontrará con animales minúsculos propios de la tradición poética japonesa. 


\section{El jardín interior}

La segunda serie de poemas de Jarro de flores, "En el Jardín”, parece representar un alto en el camino que le permite entrar en un espacio natural más estrecho. Aunque los animales aparecen aquí concentrados en un espacio organizado y escrutable, lo biológico empieza a dispersar la consciencia en fragmentos instantáneos de percepción. Esa futilidad en la percepción se expresa mejor con motivos de la tradición lírica japonesa como los insectos, según se observa en "Libélula": "Porfía la libélula / por prender su cruz transparente / en la rama desnuda y trémula" (2016/2002, p. 25). Este insecto se vislumbra como una silueta luminosa sin color que intenta formar una figura sobre una rama endeble. La luz no logra completarse y la escena se queda en el intento por alcanzar una imagen ideal, que resulta imposible. El efecto poético radica justamente en el hecho de que no se complete.

La libélula que no logra estabilidad en una rama evoca directamente un haiku de Basho: "Cuando la libélula cae de la rama / lejos voló" (Blyth, 1949, p. 215). El hecho de que Tablada halle en su jardín interior un animal propio de la poesía clásica japonesa ha servido para expresar, justamente, que la unión del poeta y el insecto no se puede realizar por la fragilidad del instante, como una imagen del vacío en el budismo zen. Tablada aporta, no obstante, la idea de una porfía o una voluntad persistente de la libélula por producir un efecto en la realidad natural, que es crear una imagen religiosa como es la cruz. Un motivo de la cultura latinoamericana viene a completar el cuadro inicialmente japonista.

Otro animal que desempeña la función budista de resaltar la fragilidad de la percepción es la luciérnaga, que aparece en el haiku "Luciérnagas": "El jardín bordan / alternativamente / con una lentejuela en cada rosa..." (Tablada, 2016/2002, p. 70). Este insecto evoca la luz efímera que llena de vida desnuda el espacio del jardín, pero la voz poética busca hallar un comportamiento humano en esa acción de tejer su propia luz en forma de lentejuelas. En el poema, el tejido no se completa porque el vuelo a la siguiente rosa no permite estabilizar la visión. Los insectos son como instancias de voluntad que confeccionan 
ornamentos humanos: la cruz o las lentejuelas, los cuales en su condición de ornamentos son motivos propiamente modernistas.

Tablada se refiere, además, a la hormiga, otro animal minúsculo del jardín, en el haiku "En Liliput": "Hormigas sobre un / grillo inerte. Recuerdo / de Gulliver en Liliput" (2016/1922, p. 68). El énfasis en este pasaje es sobre la pequeñez más que sobre la fugacidad, de ahí la comparación con los pequeños habitantes de la isla imaginaria de Liliput en Los viajes de Gulliver (1726) de Jonathan Swift (1667-1745). La escena carece de alusión al movimiento, pues las hormigas reposan sobre los restos mortales de un grillo.

Posteriormente aparecen poemas con alusiones a animales más grandes, pero todavía fugaces en el vuelo. Estos ponen el énfasis sobre la melodía de la voz poética, como ocurre en "Vuelos": "Juntos, en la tarde tranquila, / vuelan notas de Angelus, / murciélagos y golondrinas" (2016/1922, p. 70). El vuelo de animales pequeños es más difícil de sostener en la percepción que el de animales grandes. Al describir la percepción de animales voladores al final de la serie, se pone el acento sobre una transición a la serie de poemas subsiguiente. En esta transición vuelve a aparecer el canto. Una plegaria católica musicalizada irrumpe en el espacio bilógico.

En el espacio imaginario que recrea Tablada, el exotismo excede a la vida desnuda y la complementa. Estos animales minúsculos que aparecen en su jardín interior, en su paraíso artificial, son instancias de percepción del poeta que están signadas por una imagen doble: de un lado, lo oriental (espiritual) y, del otro, lo modernista con su sensualidad y su esencia ornamental, las dos a su vez efímeras y complementarias. A la vez que capta el espíritu del haiku, "sus adaptaciones metafóricas y sus variaciones métricas no tienen el propósito de re-crear los haikus japoneses sino amoldarlos a su forma mexicana de ver y sentir la vida" (Nagy-Zegmy, 2008, p. 227). Por eso, en su jardín interior no solo habita lo biológico, sino también, en un gesto modernista y a la vez muy mexicano, elementos religiosos como la cruz y el ángelus, al igual que elementos ornamentales como las lentejuelas tejidas por las luciérnagas, como imágenes caleidoscópicas. Son animales que escapan de la mirada rápida y descuidada, pero que con un poco de atención se 
observa cómo llenan el espacio y lo transforman. La mirada del poeta se despliega en diversos sentidos y se dispersa en la percepción. El viaje que empieza con los sonidos que llaman al cortijo lo llevan a reencontrarse con una nueva apreciación del entorno que lo disgrega en una multitud de escenarios diminutos. Hacia el final de la serie esta se revierte sobre animales más grandes, ya no tan efímeros a la percepción, que constituyen la transición a la próxima serie.

\section{Bestiario interior}

Los poemas que aparecen en la tercera serie, titulada "Bestiario", llevan al extremo la inclusión de motivos propios del imaginario cultural hispanoamericano y la naturaleza autóctona (Tinajero, 2004, p. 111), como el burro, el lagarto, el jaguar y el perico. Se revela el motivo del viaje a través del poema "El burrito": "Mientras lo cargan / sueña el burrito amosquilado / en paraísos de esmeralda" (Tablada, 2016/1922, p. 35). El burro es a la vez sujeto y vehículo del viaje onírico, pues es él quien sueña, pero a la vez acarrea pesadamente el objeto de su sueño: la esmeralda. El evento es apacible y a la vez violento, pues deriva de la imposición de una carga externa, absurda y sin sentido existencial. No es ya el movimiento efímero de un animal diminuto hacia la yerba, como el de la libélula que se mueve en la rama, sino el de un animal atado por el peso de sí mismo y de la piedra preciosa. Este poema manifiesta la explotación del animal como herramienta de trabajo, en una comunión violenta.

La mirada del animal pone en evidencia la presencia del yo poético que interviene en el devenir del ser natural, pero esta vez sin posibilidad de voz, lo cual se podría observar de nuevo cuando Tablada escribe en "Un mono": "El pequeño mono me mira... / ¡Quisiera decirme / algo que se le olvida!" (2016/1922, p. 38). La comunicación a través de la mirada reflejaría aquí también una conexión entre lo humano y lo biológico, con un pensamiento esquivo que trae consigo una imposibilidad del lenguaje. Aunque el animal tampoco es efímero en el movimiento ni en la percepción explícita del poeta, la fugacidad del recuerdo expresa una incompletud o la frustración de no poder capturarse del todo esa percepción en el poema. A diferencia del sapo, 
y de los animales minúsculos creadores, al mono se le atribuye una ausencia de lenguaje, que es como la pérdida de la dimensión sonora de la poesía misma.

En el último de los poemas, "Perico", Tablada escribe: "El perico violeta / cabe en su verde jaula / desprecia mi sorpresa" (2016/1922, p. 72). En este poema se expresa de forma explícita cómo el ser humano ha dispuesto del cuerpo del animal, el cual ha sido aprisionado y ha perdido la libertad. La percepción se ha alejado completamente del entorno natural como ocurría con el jardín interior. El perico desprecia la sorpresa. El nexo entre lo humano y lo animal está mediado por un elemento extraño y negativo que connota una pérdida y una imposibilidad. Aunque es un perico, ya no es uno que canta, se ha perdido la voz poética y el lenguaje. Estos animales no están en Japón, sino en México, y no forman parte del conjunto estético que se remonta a Oriente. Quizás por esto está ausente esa placidez que es propia de las imágenes poéticas que provienen de esas latitudes.

Estos animales criollos, situados en México y no en Japón, pero sí en el mundo interior, reflejarían una sensación de pérdida irreparable en la poética de Tablada. En los poemas con motivos japoneses como la luciérnaga y la libélula, el paisaje natural fluye sin contradicciones. En cambio, con animales americanos la presencia humana arremete de manera violenta como alegoría no solo del colonialismo, sino de la tecnología, como se observa en "Heroísmo": "Triunfante al fin perrillo fiel / y ahuyentado por tu ladrido / huye veloz el tren" (Tablada, 1922, p. 79). El perro vuelve a aparecer con su voz para expresar su rechazo contra lo moderno.

Sometidos a la voluntad humana, los animales en esta serie manifiestan también una sumisión silenciosa a la mirada del poeta. En la próxima serie se observará una continuidad en este sentido, pues ya el poeta parece mostrarse como dominador de la voz y la mirada a través de la estética y la intertextualidad con la poesía modernista. La próxima parada en el viaje interior será en el océano, donde los animales fluyen libremente, para ser observados y elaborados por la mirada poética. 


\section{Marinas, el mar interior}

En la cuarta serie de poemas que compone Jarro de Flores, denominada "Marinas", se puede observar cómo la mirada del poeta se traslada a un espacio marino imaginario en el que se despliegan elaborados motivos literarios, despojados de su simpleza. El poeta se manifiesta ahora como quien controla la percepción de su entorno. Tablada escribe en "Toninas": "Entre las ondas azules y blancas / rueda la natación de las toninas / arabescos de alas y de anclas." (Tablada, 2016/1922, p. 74). Las toninas o delfines surgen entre colores y arabescos como una pintura que invita a la contemplación de sus formas en toda su complejidad de colores y capas. La materialización en palabra de esa percepción muestra que, a pesar del movimiento, el poeta puede capturar esa imagen para darle expresión concreta en el poema.

La naturaleza marítima permite ser explorada en su dimensión alegórica e intertextual, ante la posibilidad del poeta para imponerse como el que marca el derrotero de la palabra. Por esta razón, la naturaleza marina puede utilizarse como metáfora del erotismo, para producir asociaciones con el cuerpo femenino que permiten mantener un poder sobre ese cuerpo y la emoción resultante. En el poema titulado "Coquillage", el poeta escribe: "La ola femenina me mostró, / carnal, la mitad de su blancura, / la concha que a Verlaine turbó" (Tablada, 2016/1922, p. 50). El coquillage o las conchas interactúan con la ola en alegoría al cuerpo de la mujer, donde el color de la ola semeja el de la piel femenina que oculta el órgano sexual entre su silueta torneada. La concha es, pues, una capa de sentido que no revela inmediatamente a la percepción lo que está oculto, que debe develarse en la interpretación.

Este diálogo del poeta mexicano con Paul Verlaine (1844-1898) resalta la dimensión intelectual de la memoria al explicitar el tema modernista, en una interacción entre lo europeo y lo oriental. La naturaleza biológica de lo erótico es un recurso poético que permite sugerir la continuidad entre el cuerpo femenino y los moluscos. Este haiku alude al soneto del mismo nombre que escribe Verlaine en "Las conchas": "Cada concha incrustada / En la gruta donde nos amamos, / Tiene su particularidad" (2007, p. 57). Verlaine describe cómo cada concha imita los movimientos de los amantes y cómo ellas reflejan 
estadios de la emoción erótica. Y culmina el soneto con un verso suelto: "Pero una, entre todas, me encantó". Así que, cuando Tablada dice "la concha que a Verlaine turbó", hace referencia a ese verso.

En otro poema, titulado "Pelícanos", también se observa una relación intertextual con poetas franceses. Tablada escribe: "Suicidas como los humanos, / clavan los grandes picos en las rocas / y se dejan morir los pelicanos" (2016/1922, p. 50). El motivo semeja la situación representada en "El albatros" de Charles Baudelaire (1821-1867), el segundo de su poemario Las flores del mal, donde el ave se presenta como un animal marítimo torpe, que a voluntad sigue al navío que lo va a cazar y luego se deja apresar sin resistencia. Esta personificación del ave permite atribuirle una actitud suicida. Sin embargo, los marineros que cazan al albatros también son alegoría de un poeta que puede aprehenderlo en la percepción. En "Pelícanos", la mirada se mantiene sobre la longitud de la escena, desde que clavan los picos hasta que se suicidan, y aún se presenta el símil explícito en "como los humanos". El control poético sobre lo biológico resulta también en una imagen doble: por un lado, la esencia contemplativa que da cuenta de un evento animal; por otro lado, el diálogo con Baudelaire, que lo inscribe también en una de las imágenes icónicas de la poesía modernista como es el ave suicida.

La dimensión marítima del viaje, pues, expresa la faceta más intelectual del poeta, pero a la vez la más pasional, en un sentimiento lleno de erotismo hacia las "conchas" marinas o un impulso hacia la muerte como el de los pelícanos, en diálogo directo con los motivos de la poesía francesa. La presencia del animal como instancia de percepción se complejiza al convertirse en alegoría explícita con referencias intertextuales. Ya no es la percepción huidiza y frágil de lo sonoro y lo luminoso. Después de haber sometido a la naturaleza animal, es posible expresar una percepción controlada y elaborada que se manifiesta en la palabra y la expresión literaturizante. Posteriormente el poeta puede entonces reunir miradas sobre el mundo natural y reconstruir su voz poética, al integrar las diversas instancias de percepción que ha recorrido través de la observación de los animales. La última serie del libro es esa etapa culminante de reorganización de esos fragmentos de percepción que conforman su identidad poética. 


\section{Dramas mínimos}

La sexta serie de haikus de Jarro de Flores es titulada "Dramas mínimos”, en alusión a los animales pequeños del haiku que vuelven a aparecer, como punto de llegada en el viaje interior, pero esta vez integrados con los animales grandes propios del entorno cultural latinoamericano. En estos poemas, se percibe la melancolía de lo transitorio y la singularidad de los seres minúsculos como una esencia y una sensación. Allí encuentra Tablada lo poético, en una instancia de percepción que reitera la trágica futilidad de la vida humana.

Se retoma el motivo de la fragilidad de la percepción en "Luciérnagas": "La inocente luciérnaga se oculta / de su perseguidor, no entre las sombras / sino en la luz más clara de la luna" (2016/1922, p. 81). La luciérnaga es vista por un momento, pero luego se difumina del perseguidor, que no es más que esa instancia de percepción que pretende aprehenderla. La imagen no puede emerger porque el instante la pone en una nueva dimensión. Paradójicamente es la propia luz que la oculta, pues no le permite mostrar la forma. Esta imagen evoca un haiku de Oshimi Ryota (1718-87): "siendo perseguida / la luciérnaga / se esconde en la luna" (Blyth, 1949, p. 217). La forma como Tablada complementa a Ryota parece entrañar el anclaje con la tradición contemplativa del zen, pero se complementa la estructura estética binaria con el modernismo.

Para el poeta mexicano la luciérnaga es "inocente" y su calificación de lo biológico es filtrada por una condición, si se quiere, moral. Para el japonés no es necesario darle un adjetivo a la luciérnaga: esta simplemente es perseguida, sin que la meta sea aprehenderla en el poema, pues la contemplación de la naturaleza es un fenómeno que puede prescindir del lenguaje. La percepción en Tablada está signada por el lenguaje que nombra las cosas y las califica. Él dice que el insecto escoge esconderse no en la sombra sino en la luz, como si intencionalmente buscara alejarse de la expresión del poeta; mientras que para Ryota el evento simplemente ocurre cuando la luciérnaga desaparece de la vista. El perseguidor, como alusión a la voz poética que desea aprehender la imagen de la luciérnaga, demarca un deseo que es ajeno a la esencia de la poesía japonesa, y así la búsqueda del poeta 
mexicano se delata. La acción efímera que es retratada nace como una intención y el resultado deviene en una reflexión poética. Ryota solo observa: la luz de la luciérnaga se funde con la de la luna y no hay nada más. El hecho poético está para el japonés en el vacío y en la futilidad de la acción.

Tablada rompe los límites de su modelo oriental y usa el lenguaje para expresar lo que le falta decir a Ryota. La dimensión de lo humano, en Tablada, se comunica con el animal para efectos de la elaboración de una imagen a través de la palabra. Con Ryota ocurre de otra forma, para él el fin del poema está en acercarse al satori, una experiencia individual que no puede expresarse con palabras y que solo se da en un contacto directo con lo biológico; este, como dice Elvira García: "no contiene abstracciones ni circunloquios, ni es discursivo, sino que se expresa por palabras cortas que conllevan imágenes" (1998, p. 98). Tablada, por su parte, juega con lo discursivo no solo a través de la luciérnaga, sino al retomar el motivo del sapo.

Al igual que en "De camino", el canto del sapo aparece, de nuevo, como metáfora de la voz poética, como en el poema titulado " 10 pm": "Canta un responso el sapo / a las pobres estrellas / caídas en su charco" (2016/1922 p. 76). Este animal canta una letanía melódica más cercana la poesía o "responso", en contemplación melancólica de una imagen de las estrellas proyectadas en el ángulo visual del animal que está próximo al agua. Así pues, puede decirse que esta nueva aparición del canto del sapo refleja la mirada sonora del poeta sobre los animales pequeños. Este regreso a la voz poética inicial le permite cerrar el ciclo, después de integrar las diferentes instancias de percepción que recopiló en los diferentes momentos de la serie y de su viaje interior.

Tablada introduce los animales míticos mexicanos, pero a ellos los presenta en ese marco inamovible y opresor de percepción que vimos en "Bestiario". Un ejemplo es el poema titulado "Jaguar": "Luce del jaguar el blasón: En campo de oro / las manchas del sol" (Tablada, 2016/1992, p. 72). Aquí el blasón indica una irrupción de lo europeo en la representación del animal. El jaguar, que es sagrado para las culturas precolombinas, resulta confinado en los marcos de un escudo. Está en campo de oro, una significación propia de la heráldica que compondría así una visión de lo mestizo y de la colonización. En "Coyoacán”, 
también se sugiere esta violencia sobre el animal ancestral: "Coyoacán, al paso del muerto / el coyote de tu jeroglífico / lanza impecable lamento" (Tablada, 2016/1992, p. 84). El animal mitológico, enmarcado ahora en el estrecho espacio del jeroglífico, se lamenta. La instancia de la percepción aquí parece estar signada por una nostalgia de lo que se ha perdido con la conquista. En todo caso, estos animales hacen posible la expresión poética, que se manifiesta en un "impecable lamento". Los animales ancestrales, entonces, al final de la serie, ya tienen su voz al igual que el sapo.

La última parte del libro, pues, no solo es un regreso a los motivos japonistas, sino a las imágenes ancestrales y autóctonas que, no exentas de exotismo, también se inspiran en una estética modernista. En ellos mezcla las diferentes instancias de percepción de su viaje interior como punto de llegada. Los animales le han mostrado diversas dimensiones de la mirada que ahora le permiten reconstruir su voz poética de una manera completa.

\section{Conclusiones}

El poemario Jarro de flores está estructurado de forma que cada serie funciona como episodios de diferentes instancias de percepción. En ellos, distintas manifestaciones de lo biológico se convierten en el objeto estético sobre el que subyace su clave poética. A través del viaje interior que emprende en la serie "De camino", el poeta se encuentra con unos animales que se convierten en vehículos de la memoria o imágenes entrañables de la infancia. Los animales aparecen emitiendo sonidos que se equiparan a cantos, convirtiéndose en metáforas de la voz poética y vehículos de percepción de lo natural. Los motivos más japonistas como el sapo coexisten con los más hispanoamericanos como el gallo y el perro, en el entorno de la granja, que se vislumbra como un regreso al recuerdo. "En el Jardín", por su parte, elabora los animales primordialmente japonistas, que se sitúan en ese espacio organizado donde la vida desnuda es inmanente a la introspección. Es allí donde la fragilidad del instante conlleva un encuentro de Tablada consigo mismo por medio de la comunión con la vida minúscula. La voz poética implica 
una mirada sobre el vuelo fugaz de los insectos. Así pues, el viaje de la granja al jardín implica un movimiento de lo sonoro a lo visual, y de lo hispanoamericano a lo japonista en los animales.

En "Bestiario", la percepción se estabiliza en la mirada sobre los animales grandes, con el burro como apertura semántica que representa la transición a esta nueva instancia de percepción. Los animales se exponen a la mirada como resultado implícito de la acción violenta y opresora que los encarcela y aprisiona. Callan, pues la voz poética parece estar reprimida en una atmósfera sin lenguaje, de animales encerrados y exhibidos como en un zoológico. Sin embargo, es en ese silencio donde es posible establecer un control sobre la mirada y esto conduce a la siguiente serie. En "Marinas", el poeta ejerce ahora un control total sobre la percepción después de haber renunciado a la fragilidad de la experiencia estética japonista. Ese espacio de exhibición estética se circunscribe al esquema estructural del verso, como en una prisión simbólica, que lo somete a alegorías e intertextualidades modernistas explícitas.

Finalmente, en "Dramas mínimos", se presenta el punto de llegada del poeta como un espacio integrador de las diversas experiencias sensoriales. La contemplación de lo espiritual y lo sublime es tan dinámica como estática y tan fugaz como permanente, a través de la integración de animales pequeños y grandes, de la tradición japonista y la ancestral autóctona. Los animales autóctonos, aunque confinados en piezas de arte, recuperan su voz. El poeta ha descubierto su voz poética en ellos en confluencia con la búsqueda japonista del sapo.

Queda por profundizar en otras dimensiones de lo biológico que se exploran en el libro de Tablada, por ejemplo, las plantas, pues ellas deberían estarse articulando semánticamente con los animales. Los minerales tienen además un papel en el peregrinaje del poeta por su propia individualidad, que suelen asociarse a lo modernista por su potencialidad ornamental. En relación con el asunto epistemológico de la percepción en sí, cabe preguntarse cómo se puede vincular con una estética neobarroca que pone en duda la posibilidad del conocimiento de la realidad a través de los sentidos, lo que ofrecería una lectura interpretativa que podría arrojar nuevas luces sobre el camino de 
la percepción en Tablada. Otros elementos poéticos, además de los animales, plantas y minerales, podrían estar teniendo una función en esa búsqueda poética global sobre la percepción y la mirada sobre la realidad.

Todos estos asuntos podrían aplicarse al análisis de otros poetas que han escrito haikus en español. La obra de Tablada fue pionera al traer un modelo lírico japonés a la lengua española. Los demás poetas latinoamericanos que han escrito haikus están en deuda con el poeta modernista mexicano. Sería una fuente de investigación literaria desentrañar los lazos entre Tablada y los demás poetas del haiku latinoamericano.

\section{Bibliografía}

Baudelaire, Ch. (1995). Las flores del mal. Bogotá: Oveja Negra.

Blyth, R. H. (1949). Haiku. Tokyo: Hokuseido.

Cobb, D. (2002). Haiku: The Poetry of Nature, New York: Universe Pub.

Díaz Ruiz, I. (ed.). (2007). El modernismo hispanoamericano: Testimonios de una generación, México, Universidad Nacional Autónoma de México.

Del Olmo Iturriarte, A. \& Díaz Castro, F. (2008). Antología de la poesía modernista española. Madrid: Castalia.

Fuente Ballesteros, R. (2009). "En torno al orientalismo de Tablada", Literatura Mexicana 20 (7), pp. 57-77.

García Alba, P. E. (1998). "El zen y el haikai en la vida de José Juan Tablada", Texto crítico 4 (6), pp. 93-107.

Giorgi, G. (2008). "Lugares comunes: ‘vida desnuda’ y ficción”, Grumo 9, pp. 48-54.

Gonzalez Duro, E. (1994-1996). Historia de la locura en España, del reformismo del siglo XIX al franquismo. Madrid: Temas de Hoy.

Hernández Palacios, E. (2001). "Juan José Tablada: Tradición y modernidad", Texto crítico 9, pp. 103-117.

Nagy-Zekmi, S. (2008). Moros en la Costa: Orientalismo en Latinoamérica. Madrid: Iberoamericana-Vervuet.

Payne, M. (2010). The Animal Part Human and Other Animals in Poetic Imagination. Chicago: Universidad de Chicago.

Prieto de Paula, Á. (2002). "Subjetivación, irracionalismo, música: Rasgos del simbolismo en la poesía española hacia 1900", Anales de Literatura Española 15, pp. 55-70. 
Salvador, Á. (2005). "José Emilio Pacheco y los animales". Cuadernos hispanoamericanos 71/72, pp. 115-125.

Tablada, J.J. (1922). El jarro de flores: Disociaciones líricas. Nueva York: Escritores Sindicados.

Tablada, J.J. (2016/1922). The Experimental Poetry of José Juan Tablada. A Collection in Spanish and English. Ed. A. Scott Britton, Jefferson, NC: McFarland.

Tanabe, A. El japonismo de José Juan Tablada. México: Universidad Autónoma de México, 1981.

Tinajero, A. (2004). Orientalismo en el modernismo hispanoamericano. West Lafayete (Indiana): Purdue University.

Verlaine, P. (2007). Fiestas galantes, Trad. Manuel Machado. Madrid: Renacimiento. 